Article

\title{
Compact Cities Are Complex, Intense and Diverse but: Can We Design Such Emergent Urban Properties?
}

\author{
Hye Kyung Lim * and Jaan-Henrik Kain \\ Department of Architecture, Chalmers University of Technology, 41296 Gothenburg, Sweden; \\ E-Mails: kyung@chalmers.se (H.K.L.), kain@chalmers.se (J.-H.K.) \\ * Corresponding author
}

Submitted: 16 December 2015 | Accepted: 8 March 2016 | Published: 30 March 2016

\begin{abstract}
Compact cities are promoted by global and local policies in response to environmental, economic and social challenges. It is argued that increased density and diversity of urban functions and demographics are expected to deliver positive outcomes. 'Emerged' urban area which have developed incrementally seem to exhibit such dense and diverse characteristics, acquired through adaptation by multiple actors over time and space. Today, 'design-based' planning approaches aim to create the same characteristics here and now. An example of such is the City of Gothenburg, Sweden, which strives to involve multiple actors to 'design' urban density and mixed use, but with unsatisfactory outcomes. There is reason to investigate in what way current planning approaches need modification to better translate policy goals into reality. This paper studied which type of planning approach appears to best deliver the desired urban characteristics. Two cities are studied, Gothenburg and Tokyo. Today, these cities operate under different main planning paradigms. Tokyo applies a rule-based approach and Gothenburg a design-based approach. Five urban areas were studied in each city, representing outcomes of three strategic planning approaches that have been applied historically in both cities: 1) emergent compact urban form; 2) designed dispersed urban form; and 3) designed compact urban form. Planning outcomes in the form of density, building scales and diversity were analysed to understand if such properties of density and diversity are best achieved by a specific planning approach. The results show that different planning approaches deliver very different outcomes when it comes to these qualities. To better support ambitions for compact cities in Gothenburg, the prevailing mix of 'planning by design' and 'planning by developmental control' needs to be complemented by a third planning strategy of 'planning by coding' or 'rule-based planning'. This is critical to capacitate urban planning to accommodate parameters, such as timing, density, building scale diversity, and decentralization of planning and design activities to multiple actors.
\end{abstract}

\section{Keywords}

compact city; density; diversity; emergent urban form; rule-based planning; urban adaptability; urban resilience

\section{Issue}

This article is part of the issue "Urban Forms and Future Cities", edited by Luca D'Acci (Erasmus University Rotterdam, The Netherlands), Tigran Haas (KTH Royal Institute of Technology, Sweden) and Ronita Bardhan (Indian Institute of Technology Bombay, India).

(C) 2016 by the authors; licensee Cogitatio (Lisbon, Portugal). This article is licensed under a Creative Commons Attribution 4.0 International License (CC BY).

\section{Introduction}

\subsection{Compact City Policies}

Global and European policies on urban development promote the 'compact city' concept as a response to challenges such as climate change, environmental issues, economic development, social cohesion and attractivity. A number of recent UN-Habitat reports and policy papers argue that compact city structures have positive effects on citizen health, economy, resource efficiency, social cohesion and cultural dynamics (UN 
Habitat, 2011, 2014a $\left.{ }^{1}, 2014 c, 2015\right)$ and that low population density is the most environmentally harmful urban form in both mono-centric and polycentric urban structures (UN Habitat, 2014b).

This line of argument is picked up by European Union policy documents, arguing that a compact and diverse city structure has positive effects on citizen health, economy and efficient use of resources (Commission of the European Communities, 2011), and that cultural, social and political dynamics are promoted by density, proximity and diverse choices available within compact cities (Commission of the European Communities, 1990). The OECD, claims that compact city policies will result in lowered $\mathrm{CO}^{2}$ emissions and reduced energy consumption in transportation, not only on the metropolitan scale but also on the neighbourhood scale, but also in conservation of farmlands and biodiversity, and in reduction of infrastructure cost and increase of labour productivity (OECD, 2012).

In Sweden, the City of Gothenburg's visions and policies are developed along these lines, promoting dense and mixed use urban patterns to reduce socioeconomic segregation and increase liveability, e.g. in the Rivercity Gothenburg Vision (Gothenburg City Council, 2012) and the Development Strategy Gothenburg 2035 (Planning and Building Committee of Gothenburg, 2014).

\subsection{The Compact City Paradox}

As we can see, urban development policies at all levels favour dense and diverse urban patterns. Such policies are supported by the proponents of the agglomeration effects (e.g. Glaeser, 2011) rendered by the proximity of diverse urban components, leading to mixed land use, diversity of demographics and diversity of scales. It is claimed that such qualities provide better economic output (Quigley, 1998) and higher invention rates by providing fertile ground for knowledge spillover (Carlino, Chatterjee, \& Hunt, 2007; Glaeser, 2011), reduced energy use through employment density (Mindali, Raveh, \& Salomon, 2004), and alleviate social segregation (Burton, 2001). It is also argued that dense and diverse urban patterns are more resilient forms of urban structure, providing a redundancy of functions (Bettencourt \& West, 2010), networkability and responsediversity to disturbances (Bristow, 2010; Glaeser, 2011; Offenhuber \& Ratti, 2014).

However, compact city policies are also contested in research. It is argued that neighbourhood density might impact negatively on neighbourhood satisfaction (Bramley \& Power, 2009), sense of attachment and sense of quality of public utilities (Dempsey, Brown, \& Bramley, 2012), and psychological health due to overcrowding (Haigh, Ng Chok, \& Harris, 2011). Furthermore, critics of 'Compact city' argue against the concept, highlighting

${ }^{1}$ Urban planning discussion note3. the bigger income gaps, increased ecological footprint due to higher consumption (Heinonen \& Junnila, 2011), decreased living space for low income groups and accessibility issues to green space and nature areas (Burton, 2001). Still, negative social problems related to density may be due to the characteristics of the urban areas where poverty is concentrated, rather than to the urban form itself (Bramley \& Power, 2009). Increased consumption rates and larger income gaps might be linked to the incidents of accumulation of wealthy population as well as low income population in dense urban areas, not to the urban form itself (Glaeser, 2011). Since crowding is a problem of perception of urban space, this may also be attributed to a design problem and not intrinsically linked to urban compactness (Kearney, 2006).

The correlation between urban problems and urban form is thus unclear. There is a risk that generic problems of urbanization are criticized as being problems of compact cities. As Edward Glaeser puts it: 'Cities do not make people poor; they attract poor people. The flow of less advantaged people into cities from Rio to Rotterdam demonstrates urban strength, not weakness' (Glaeser, 2011, p. 9).

One explanation of the contradictory findings is the persistent lack of clear definitions for what a compact city actually is (Neuman, 2005). The classifications listed in the UN-Habitat's and other policy papers are general, and do not provide concrete guidelines for global implementation. Even if several attempts have been made to establish 'compact city' or 'sprawl' indexes, the heterogeneity of the concepts of density (Churchman, 1999; Manaugh \& Kreider, 2013), and diversity (Manaugh \& Kreider, 2013), and prevalence of different indexes (Lee, Kurisu, An, \& Hanaki, 2015) is problematic for the practical implementation of policy. Another explanation is that the positive properties of compact cities are found in research on urban economics (Bettencourt, 2013; Glaeser, 2011) while research showing negative effects focus on psychological impacts (Haigh et al., 2011), lowered satisfaction (Bramley \& Power, 2009), and higher consumption rates (Heinonen \& Junnila, 2011).

Due to such inconsistencies in research, there is a risk that the notion 'compact city', ends up as a 'boundary object' similar to concepts such as 'resilience' (Wilkinson, 2011) and 'sustainable development' (Muraca \& Voget-Kleschin, 2011), vague enough to justify any type of urban development (Leffers, 2015). However, seeing the notion of the 'compact city' as a boundary object also shifts the focus towards urban transformation as a process (Brand \& Jax, 2007). Leaving the critique offered by Neuman regarding the benefits of more compact cities aside for the moment, his argument that 'form is both the structure that shapes process and the structure that emerges from a process' (Neuman, 2005, p. 22) merits further consideration. If form 'is an outcome of evolution' (Neuman, 2005, p. $23)$, then the arrangement of how to undertake plan- 
ning in ways that support and guide such an evolutionary process becomes a key issue. Assuming that dense and diverse urban patterns may be beneficial, we need to understand more regarding what types of planning approaches can best promote such properties. There is a need to focus planning evaluation on the implementation of plans, not least in the context of the growing interest in urban form as the spatial concretization of urban sustainability (Oliveira \& Pinho, 2010). This paper therefore aims to contribute to such evaluation efforts by responding to the question: What are the differences in outcome of different planning approaches in relation to urban characteristics, such as density and diversity?

Note that this study will only deliver a partial answer to this question, due to the limitation of the conducted study. The following section introduces the understanding of cities as complex systems which will be used as the theoretical underpinning for the study. Thereafter, the methods used to gather and analyse data are described and the two case cities are introduced. The next section presents the results from the study. Finally, the results are discussed and some conclusions are presented.

\section{Cities as Emerging Complex Systems}

The challenges facing cities are increasingly more complex due to the dispersion of power, the divergence of agents, increasing information flows and channels, and the prevailing processes of globalisation (Homer-Dixon, 2011). This complex urban condition is continuously exacerbated by the unpredictability of internal and external factors, such as climate change, sudden demographic changes and financial crisis (Davoudi et al., 2012).

Resilience studies pay particular attention to the problematic of unpredictability, although with a variety of interpretation of the meaning and application of the term (Chelleri \& Olazabal, 2012). In the urban context, evolutionary resilience appears appropriate (Davoudi et al., 2012), denoting the ability of a system, not only to bounce back from events causing a shock through robust behaviour, but also to adapt and learn from the past behaviours to surpass the previous state by extending its capacity (Gunderson \& Holling, 2002). Such an evolutionary and adaptive view of resilience emphasizes characteristics of discontinuous change, chaos and order, self-organization, and nonlinear system behaviour (Gunderson \& Holling, 2002).

Self-organising in conjunction with nonlinear system behaviour, might increase an urban system's capacity for adapting and learning through complex interactions of the rational behaviour of individual 'micro' agents to adapt to changes, collectively rendering a 'macro' adaptive urban emergence that is unintentional (Manesh \& Tadi, 2011; Rowley, 1994).

Such emerging complexity is seen as beneficial compared to simplification, as it increases (Marshall, 2012):

1) Perceptual richness, where humans fare better psychologically in complex environment;

2) Functional capacity through properties such as hierarchy, flexibility, redundancy and specialization of different parts;

3) Synergy, where the entirety is greater than the sum of the parts.

When compared to the guidelines found in global policy on urban development, the evolutionary resilience approach to urban planning seems to deliver the outlined characteristics of compact cities. This is achieved through system properties, such as multi-functionality, redundancy and modularization, biodiversity and social diversity, multi-scale networks and connectivity, and adaptable planning (see Figure 1).

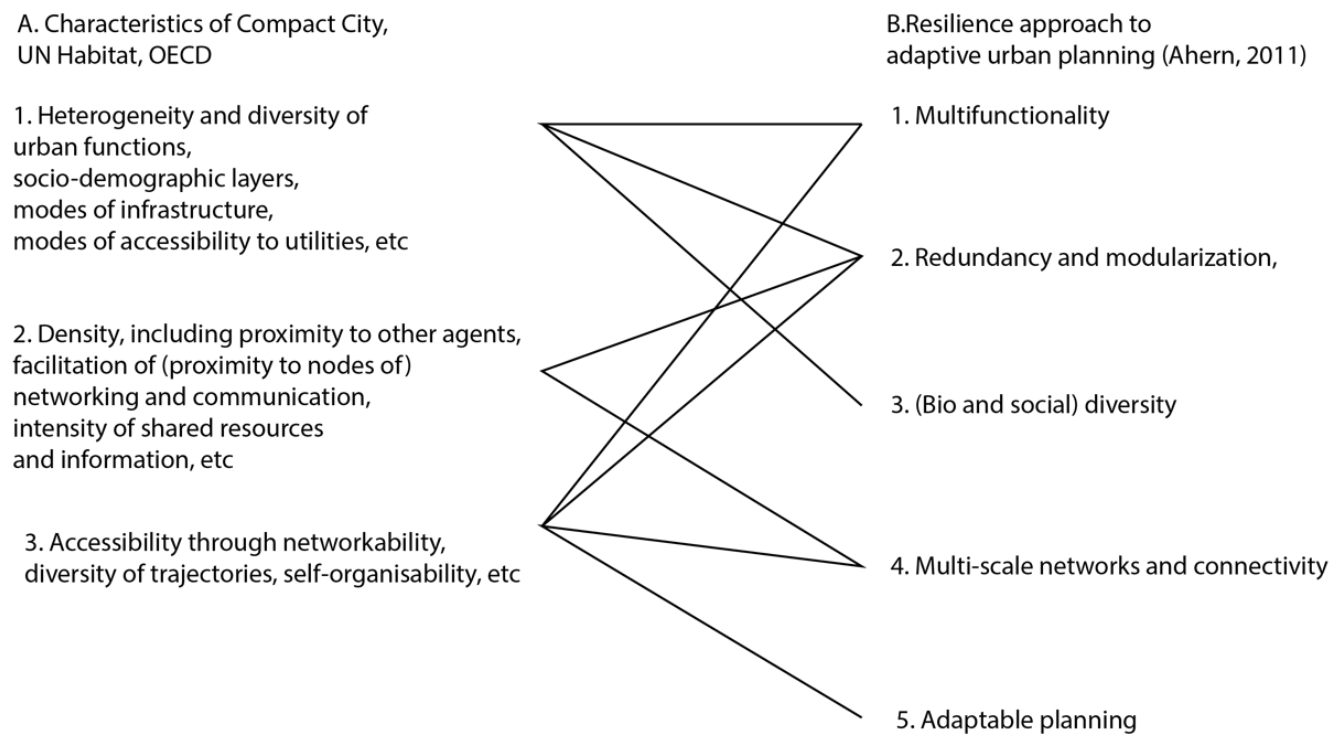

Figure 1. Policy characteristics of compact cities with properties delivered by a resilience approach to urban planning. Based on Ahern (2011), OECD (2012), and UN-Habitat (2014a). 
Resilient urban properties that relate to increased diversity, networks and increased number of agents through density and proximity are often seen in emergent urban areas that have developed incrementally through time, such as European medieval cities (Marshall, 2012; Scheurer, 2007), certain districts of Asian mega-cities and various informal settlements, for example Dharavi in Mumbai (Echanove, 2013).

Emergent systems are defined as systems with a simpler higher order behaviour, that arises from underlying complex interactions; similar to cells emerging from interactions of atoms, society emerges from interactions of people (Page, 2011). Such micro-agent interactions and adaptations at the individual networking level continually create new emergence and increase the robustness of the whole system (Alexander, 1965; Bettencourt, 2013). Also, an urban fabric created by multiple actor layers, incrementally developed with a diversity of building types, scales and functions, is often seen as having the attributes of a more intense and livelier street lives (Eom \& Cho, 2015; Jacobs, 1961; Merlino, 2011).

In contrast, modernist planning has focused on idealized plans developed top-down to deliver perfection at the moment of creation, based on control systems correcting 'problems of yesterday' with a 'conventional toolkit' (Taylor, 2003, p. 157; cited in Davoudi et al., 2012; Batty \& Marshall, 2012). This planning approach has been criticized for creating simplified and rationalized urban forms out of diverse agendas, including reduced density and separation of urban functions (Alexander, 1965; Marshall, 2012). Alexander (1965) argued that 'planning' cannot reproduce the complex characteristics of urban forms and interactions that have developed incrementally and interactively. Still, attempts have been made to emulate compact city characteristics in post-modern contexts, i.e. diversity of functions and density. Typically, this has been attempted by trying to shape emergent characteristics or forms through site specific designs (Marshall, 2012; Neuman, 2005). However, Marshall (2012) points to the difficulty of planning the kind of urban complexities which are seen in traditional emergent urban forms, through intervention and organization. Large open systems, are impossible to plan without having a complete knowledge of the consequences of such interventions, which evidently is impossible (Marshall, 2012). Marshall and Batty (2012), instead, argue that the challenge is to devise the sort of plan or design which creates the desired functional complexity. Here, Marshall (2012) identifies three planning types that, when combined into a system of planning types, can promote urban complexity:

1) Planning by design: Master planning, urban design, or outlines of design, with a preconceived conception of the finished state of a specific whole entity;
2) Planning by coding: Use of generative codes to define generic components or relationships of building blocks. Non site specific. Their use can be generative with specification to how elements can be combined to generate an aggregate urban form;

3) Planning by development control: Enabling public authorities' influences on what is allowed to be built or not by approving or rejecting specific designs or layouts proposed by private individuals or master planners.

Marshall describes the role of the 'code' in 'planning by coding', as a generative code that 'provides a framework within which individual designers can work' (Marshall, 2011, p. 230). Here, the use of codes for recording landownership in European traditional urbanism have been noted 'as of the earliest and most constant form of written urban memory-structure' (Shane, 2005, p. 25).

In summary, four main outcomes of planning can be distinguished that are helpful for analysing how different planning types relate to the processes of developing dense and diverse urban patterns (see Table 1).

Table 1. Four outcomes of two main planning types. Adapted after Marshall (2012).

\begin{tabular}{lll}
\hline Form & $\begin{array}{l}\text { Approach Planning by } \\
\text { coding }\end{array}$ & $\begin{array}{l}\text { Planning by } \\
\text { design }\end{array}$ \\
diversity & A. & C. \\
& Functional & Functional \\
& simplicity & separation \\
& Continuous & Ready-made \\
& adaptation & neighbourhoods \\
High density and & B. & D. \\
diversity & conctional & Simulated \\
& Complexity & complexity \\
& Continuous & No adaptive \\
& adaptation & capacity \\
\hline
\end{tabular}

A. Emergent dispersed urban form: Planning by coding with no compact city ambitions leads to sprawling patterns and uniform uses. Although continuous adaptation takes place, low diversity decreases the capacity to quickly evolve into new emerged states.

B. Emergent compact urban form: Planning by coding aimed at high density and diversity facilitates incremental and individual micro interactions through time and space by multiple actors. Since emergence is continuous and diversity is high, such urban systems have the possibilities to change and adapt to create new emerged states.

C. Designed dispersed urban form: Planning by design, where rationalization and simplification 
create compartmentalized urban patterns. Typical for modernistic and top-down planned urban systems, these plans are often executed through large-scale site interventions with longterm projections into the future.

D. Designed compact urban form: Planning by design-often in combination with planning by development control-are often applied in new initiatives to emulate emergent compact city characteristics. They are initiated topdown and focuses on functional diversity, density as well as on diversity of property ownerships. As designed urban systems, they often include large site areas and incrementality is negligible.

Of these four planning outcomes, $C$ and $D$ are the most relevant for analysing initiatives to produce more compact cities, while outcome $B$ is relevant to include in any analysis due to the persisting legacy into current days of the modernistic approach to urban planning and development.

\section{Method}

According to UN-Habitat (2015), density is measured in terms of the density of built areas and population, and of the concentration of urban functions. When it comes to diversity, both mixed land use and social makeup are included. Mixed land use is defined as a variety of compatible land uses and functions and provision of a cross-section of residential, commercial and community infrastructure in neighbourhoods. Social mix is defined as the presence of residents from different backgrounds and income levels in the same neighborhood, and suggested to be achieved by the availability of different housing options in terms of price ranges, tenure type and building types, and the availability of diversity of jobs in the proximity (UN Habitat, 2015).

However, as urban planning takes place in open systems with many purposeful parts (i.e., people and organizations pursuing their interests), it is difficult to link planning activities to outcomes in the urban reality (Laurian et al., 2010). Therefore, this study has chosen two highly institutionalized planning systems-in Sweden and Japan-to increase the likelihood that planning has in fact affected the urban reality. Three indicators for compact city urban form were used for the assessment of dense and diverse built environments: the density of built objects, the scales of built objects and the distribution of the diversity of the built objects. Data on these indicators was developed through analysis of building footprints. Analysis of building footprints is evidently insufficient for representing the wide spectrum of qualities to be found in, or realized through, the compact city. However, building footprints represent the building coverage ratio of a site and can indicate both street level density and diversity in the form of urban grain sizes and rhythm, diversity of building types, and diversity of urban parcel distribution. As an example, the size of individual plots of land play a role for promoting subsidiarity in decision making to better satisfy local needs (Hoffmann-Axthelm, 1993, 1996, cited in Scheurer, 2007). Nevertheless, a remaining limitation is that building footprints never can include building volume and related intensity of land use, a weakness common to any analysis solely based on land use.

The assessment was applied to three different kinds of planning outcomes (urban fabrics) resulting from two types of planning approaches as seen in Table 1 above. These were 'emergent compact urban form' achieved through planning by coding, 'designed dispersed urban form' achieved through planning by design, and 'designed compact urban form' achieved through planning by design in combination with planning by development control. Both 'emergent compact urban form' and 'designed compact urban form' are expected to deliver some degree of density and diversity while 'designed dispersed urban form' is seen as a control indicator for comparison purposes.

As case material, we selected urban fabrics corresponding to the abovementioned planning outcomes in one city, where the socio-cultural and historical context is similar. The result is then compared to similar urban fabrics in another city with other contextual relationships. The expectation was that identifying similarities and disparities within a city and between both cities would give insights into how density and diversity in more absolute terms are influenced by what planning approach has been applied. The study thus analysed three housing areas in Gothenburg and Tokyo, respectively, chosen to represent:

1) Emergent compact urban form (Type 1): An inner city urban fabric evolved through time by multiple actors' interactions;

2) Designed dispersed urban form (Type 2): $A$ modernist urban fabric from 1960-1970's where the ideology was clearly to separate and create separation between the functions and to give uniform characteristics and standards;

3) Designed compact urban form (Type 3): An inner city urban fabric where density and diversity has been designed by a number of developers simultaneously.

The two cities are evidently incomparable both in scale and in sociocultural, political and historical contexts. However, in this study, the comparison was undertaken regarding relative proportions of density and diversity across the urban areas. 


\subsection{Gothenburg and Tokyo}

The city of Gothenburg has 544,261 in population and 1,209 persons $/ \mathrm{km}^{2}$ in population density (Gothenburg City Council, 2015).

In Gothenburg, as in many other European cities, much of the development has been planned top-down by planners and architects through large-scale developments. However, the small city core developed before the 19th century has been left largely untouched. The period from $1961-1980$ has produced $42 \%$ of the building stock constructed from 1931 until 2014 (Statistics Sweden, 2015). The city districts created during the Million Program period are identified as problem areas ridden with segregation issues (Lilja \& Pemer, 2010).

Today, the City of Gothenburg is direly needs to increase its level of housing and to reduce socio-spatial segregation. The lack of housing and a constant increase of the population leads to a waiting period, counting from start of the search to a rental contract, reaching almost 4 years (Boplats, 2014). The persistent socio-economic spatial segregation coupled with a division into 'immigrant' and 'native Swedish' populations is also highly problematic (Lilja \& Pemer, 2010). Integration proceeds slowly and the quality of urban life is very much inferior to that in the Million Program areas where the immigrating population consists of up to $80 \%$ of the total population (Gothenburg City Council, 2013).

As a response to these problematic issues, Gothenburg is currently adopting a strategy based on involvement of multiple actors, e.g. by employing a diversity of firms to 'design' new urban areas with mixed tenancy types and functions (Gothenburg City Council, 2011, 2012, 2014). Although this strategy needs to be assessed further after a longer time period, it has so far been criticized for failure to produce the desired compact dense and mixed urban areas, especially with controversial issues concerning gentrification (Thörn, 2013).

Tokyo houses more than 13 million people (Tokyo Metropolitan Government, 2012). Its 23 central special wards have a population of 9.2 million and a density of 14,818 persons $/ \mathrm{km}^{2}$.

Most of the urban areas of Tokyo has emerged through continuous incremental adaptation over time. The post WWII land reform, saw $19,180 \mathrm{~km}^{2}$ of land force-purchased from 2,341,000 landlords and sold to $4,748,000$ tenants significantly reducing the individual size of holdings. This led to piecemeal development with rather un-organized individual development initiatives and composite mix of building types (Kawagoe, 1999). The city is seemingly chaotic with a rather formless urban structure due to it piecemeal developments on narrow streets, but it still keeps its traditional urban patterns quite intact. According to a study on residential class segregation, Tokyo demonstrates low class segregations based on occupation distribution, providing a juxtaposition of demographics (Fujita \& Hill, 2012).

\subsection{Study Areas}

The ten study areas in Gothenburg and Tokyo (see Figure 2) were chosen according to the applied planning approaches these include:

Type 1: Emergent compact urban form, evolved incrementally by multiple actors through time and space

A) Gothenburg Central area: Two areas developed from the $17^{\text {th }}$ century representing one of the oldest neighbourhoods in the city.

1) Inom Vallgraven: Until 1864, when the city extended southwards, this area was the core of Gothenburg and still is a very central area of the city (Stadshem, 2015b), with a population of 3,917 (Gothenburg City Council, 2014).

2) Järntorget/Haga: Previously developed with small wooden houses where port workers resided. Larger buildings were built densely in the area from around the 1840's when industry began attracting larger numbers of workers (Stadshem, 2015a). The population is 5,718 (Gothenburg City Council, 2014).

B) Tokyo Central areas: Two mixed neighbourhoods with diverse functions located in the central districts of Tokyo, selected to represent typical urban patterns found in the central areas of the Tokyo metropolis. Both areas have been developed since the Edo period of the 1600's.

1) Nishiazabu: Located in Minato ward, in central Tokyo, with a population of 10,523 (Minato City, 2012).

2) Ebisu: Situated in Shibuya ward, also located in central Tokyo, with population of 13,019 (Shibuya City, 2010).

Type 2: Designed dispersed urban form, reductionist and top-down

C) Gothenburg Million Program Area. The 'Million Program' refers to a Swedish public housing program operated between 1965-1974 to deliver one million housing units (Nationalencyklopedin, 2015).

1) Hjällbo: Among the 7,273 residents, around $60 \%$ are born outside of Sweden. $15 \%$ are foreign citizens and $45 \%$ have Swedish citizenship. Statistics show a persistently higher percentage of population on social security benefits in the district, on average $8-10 \%$ from $2000-2007$, compared to a $1-2 \%$ average in Gothenburg during that period (TILLIT, 2012). 
D) Tokyo New Town areas, referring to satellite districts developed around major cities by the Japan Housing Corporation to provide modern affordable apartments to the masses of workers migrating to the cities during the 1960's. The features of the New Towns were attempts to emulate Western and modern ideal living with greenery and parks (Yokohari, Amemiya, \& Amati, 2006). Both New Towns in this study face challenges due to decreasing populations (Ducom, 2008; The Japan Times, 2013).

1) Chiba New Town: This suburb was developed from 1969 and onwards and contains a population of approx. 143,300 people (Chiba Prefecture Government, 2013).

2) Tama New Town: This development took place from the mid 60's until the mid 80's (Ducom, 2008). According to the sensus in 2010, Tama New Town hosts 216,400 people (Bureau of urban development Tokyo Metropolitan government, 2010).

Type 3: Designed compact urban form, diversityoriented to emulate emergent characteristics

E) Gothenburg Waterfront: Two areas on the
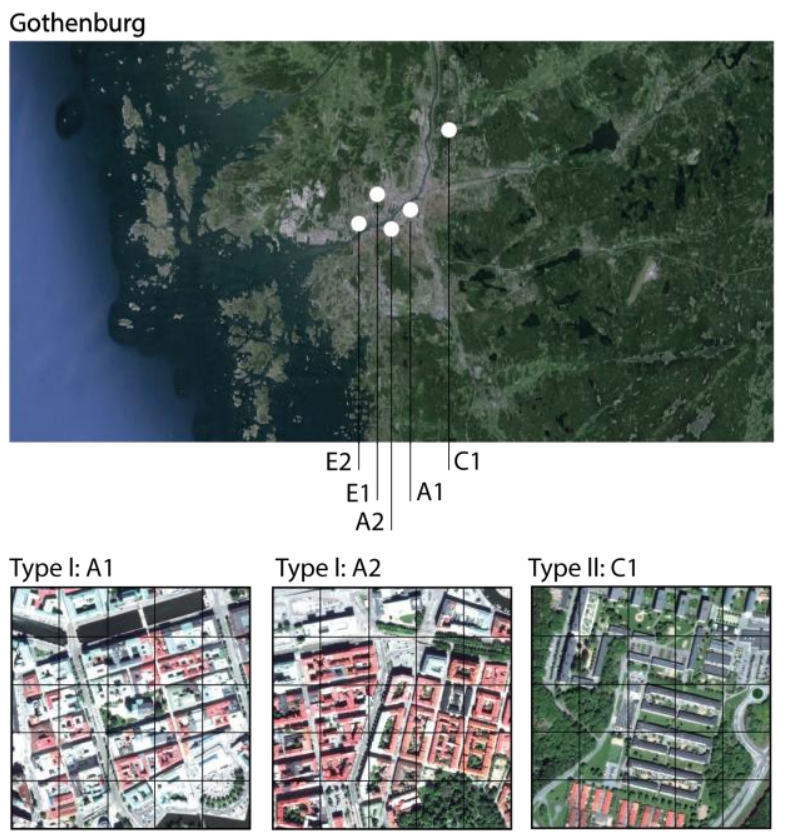

Type III: E1
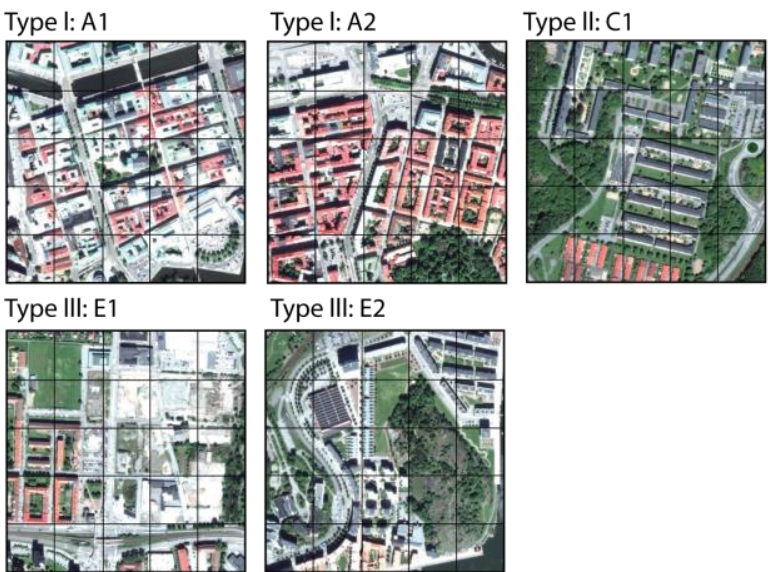

Tokyo
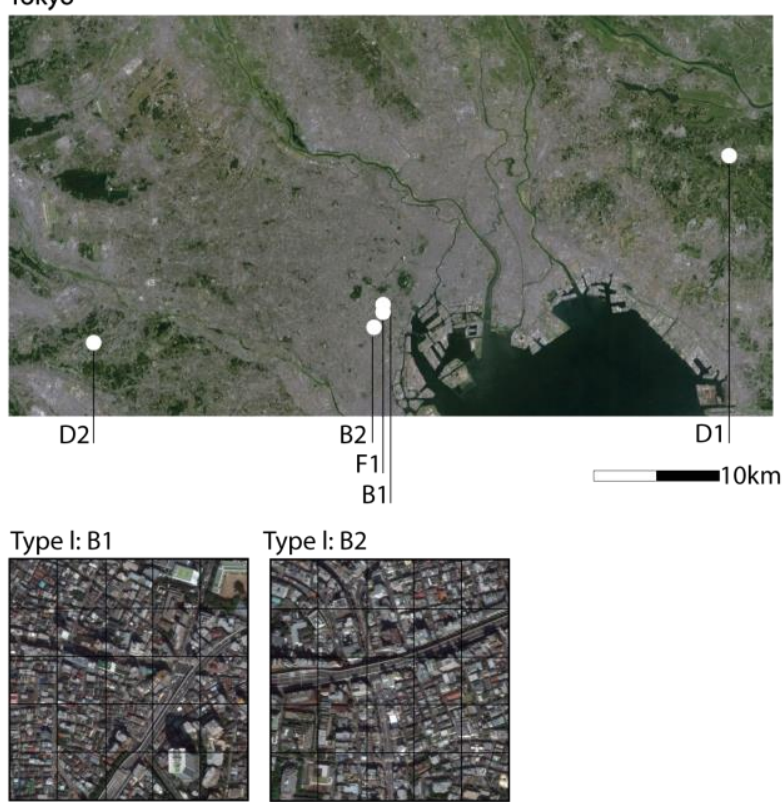

Type II: D1

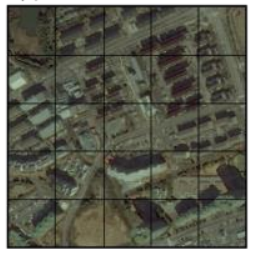

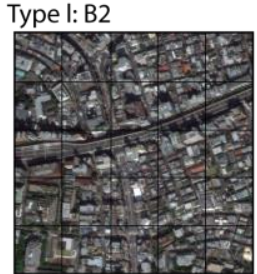

Type II: D2

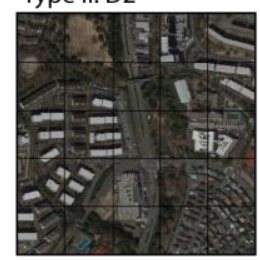

Type III: F1

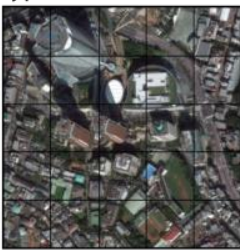

North of the Göta river represent ongoing urban intensification projects developed by the municipal agency, Älvstranden Development Ltd.

1) Kvillebäcken: 2,000 new apartments and offices/commercial functions are recently finalized, where seven firms were hired to design designated sites with a mix of tenancy types and functions in incremental development stages.

2) Eriksberg: 2,200 housing in different forms and tenure types are to be built on a disused shipyard from 2006 to 2019. A consortium of six construction firms and the municipal agency is involved in the planning and development of this area.

F) Tokyo Central area:

1) Roppongi Hills: Tokyo metropolis' response to a compact city within the central special wards. This urban intensification project was constructed by Mori building corporation and was completed in 2003. The complex with total floor area of $724,000 \mathrm{~m}^{2}$ contains offices, commercial activities, residential units and cultural activities.

Figure 2. The ten study areas in Gothenburg and Tokyo. 


\subsection{Analytical Tools}

Each chosen study area was overlaid with a grid of 25 cells measuring 100 by 100 meters, thus covering $10,000 \mathrm{~m}^{2}$ each. The cells were numbered from 1 to 25 starting shown in image 4 in Figure 3. Each cell was analysed individually. Applying the analysis on cells provided results based on a continuous urban fabric, i.e. not based on project sites. The reason for implementing this approach was to gain understanding of the areas as continuous space, including transitional points between different quarters, blocks or projected sites, encompassing urban patterns from various time periods.

The subsequent analysis of density and mixed use was based on three indicators: the density of built objects; the scale of building footprints; and the distribution and diversity of building footprints.

\subsubsection{The Density of Built Objects}

The building footprints were used as indicator for density. The study of the built environment was achieved through analysis of open source maps retrieved from openstreetmap.org. The assessment of density was performed by analysing the raster image pixel counting. The vector shapes, which identify the borders of buildings, were separated from the rest of the information, such as roads, paths and site boundaries (see image 3 in Figure 3). This gave a gross density including public and private streets as well as unbuilt surfaces. Then the colour scale of the vector polygons representing building footprint was reduced to black, i.e. with

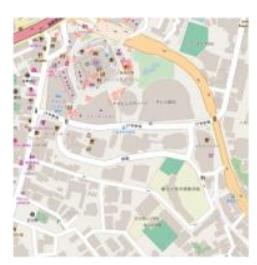

1. Site Area Openstreetmap.org

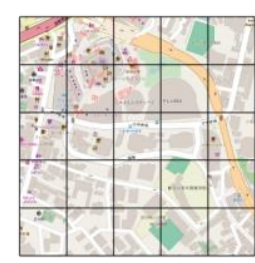

2. Grid of 25 cells of $100 \mathrm{~m} \times 100 \mathrm{~m}$ are overlayed on the site area.

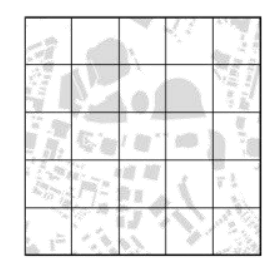

3. Building footprints are extracted.
$\operatorname{red}(R)$, green $(G)$ and blue(B) in the RGB scale reduced to $0 \%$. Through this measure, the density of $B C R$ could be derived as $100-R G B \%=x \%$ where 'RGB' is the remaining space excluding the building footprints.

\subsubsection{The Scale and Distribution and Diversity of Building Footprints: Phase 1}

The assessment of scale was done by measuring the size of the footprint of each building. To do this, the vector polygons representing the building footprints of the study areas were imported to the Adobe Illustrator software and consequently, a vector analysis script, 'SelectPathBySize.jsx' was executed for the analysis scales of built objects.

1. The script analysed areas smaller (or in ' $f$ ' below identical or bigger) than a certain surface area. The parameters of the building footprint areas used for the calculation were:
a. smaller than $300 \mathrm{~m}^{2}$
b. smaller than $750 \mathrm{~m}^{2}$
c. smaller than $1,500 \mathrm{~m}^{2}$
d. smaller than $2,250 \mathrm{~m}^{2}$
e. smaller than $3,000 \mathrm{~m}^{2}$
f. bigger than $3,000 \mathrm{~m}^{2}$

Each identified built object for a scale was removed and color-coded (see Figure 4), leaving only those larger than the values already analysed to be assessed further. The built objects larger than $3,000 \mathrm{~m}^{2}$ were grouped together without further subdivision.

Figure 3. Process of analysis of building footprints in site areas with grids.

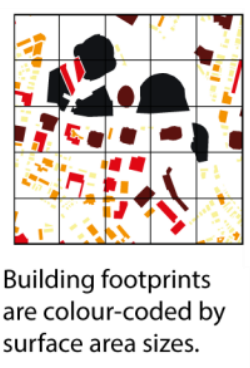

Legend: Building footprint surface area

\begin{tabular}{|c|c|}
\hline$<300 \mathrm{~m}^{2}$ & $<1,500 m^{2}$ \\
\hline$<750 m^{2}$ & $<2,250 \mathrm{~m}^{2}$ \\
\hline
\end{tabular}

Figure 4. Analysis process of scale proportions: Phase 1. 


\subsubsection{The Scale and Distribution/Diversity of Building Footprints: Phase 2}

Subsequently, each cell with the categorically colorcoded vector polygons were imported to the Adobe Photoshop software as separate layers and analysed with a histogram function to calculate the number of pixels of the combined area of a given scale object within a cell. The proportion of each building scale was then derived in relation to the total number of pixels in each cell (see Figure 5).

\section{Results}

Displayed below (Figure 6), are the results of the analysis of density, scale and distribution/diversity of building footprints.

Figure 6 illustrates the analysis of the density of built objects. It shows the building coverage ratio in the ten areas in Gothenburg and Tokyo. It showed that in Gothenburg the highest density of $37 \%$ and $31 \%$ in type 1 and the lowest, 12\% in type 2 and low density, 19\% and $14 \%$ in type 3 . In Tokyo, the study areas in type 1 and 3 showed similar density, 29\%, 26\% and respective- ly, $29 \%$, while both areas in type 2 showed the lowest density of $15 \%$.

The median values of density of the two cities showed that both the highest and the lowest density clusters were found in Gothenburg (in the 50\%-60\% and $0 \%-10 \%$ spectra), while the distribution was more evenly clustered in Tokyo (between 10\%-40\%) (see Figure 7 and Figure 8). It was also notable that the number of unbuilt neighbourhood areas represented by the cell on the $0 \%$ axis were much higher in Gothenburg.

Figure 9 illustrates the first phase of analysing the scale and distribution/diversity of building footprints. Through colour coding it facilitates the visualisation of the variation of building types and the street patterns.

The second phase of analysing scale and distribution/diversity of building footprints is illustrated in Figure 10, showing the differences between Gothenburg and Tokyo in terms of scale distribution of the building footprints. Smaller scale buildings were much more frequent in Tokyo for all urban types. Building footprints of under $750 \mathrm{~m}^{2}$ consisted of $32 \%$ and $24 \%$ of all buildings in Tokyo, while in Gothenburg the percentages for those scales were $4 \%$ and $22 \%$, respectively.

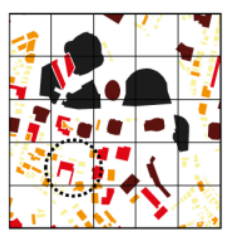

1. Colour coded site area in Roppongi

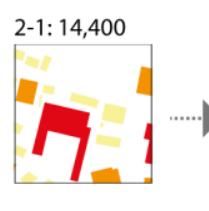

2. Analysis example of cell \#9
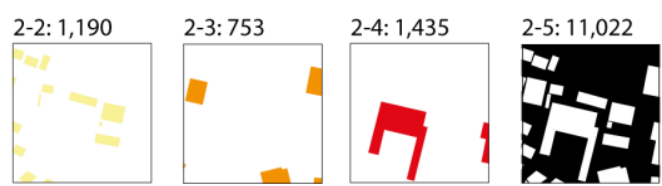

2-1. Total number of pixels in one cell

$2-2$. Number of pixels for objects $<300 \mathrm{~m}^{2}$

2-3. Number of pixels for objects $<750 \mathrm{~m}^{2}$ and $>300 \mathrm{~m}^{2}$

$2-4$. Number of pixels for objects $<1,500 \mathrm{~m}^{2}$ and $>750 \mathrm{~m}^{2}$

2-5. Number of pixels for unbuilt area
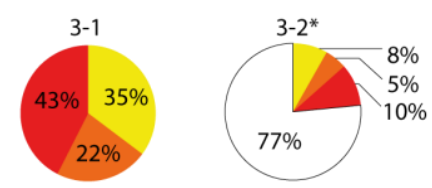

3. Visualisation of analysed scale proportion 3-1. Scale proportions of buildings in a cell 3-2. Total scale proportions of the cell** * The total scale proportions are only analysed for the whole site areas, not individual cells

Figure 5. Analysis process of scale proportions-Phase 2.

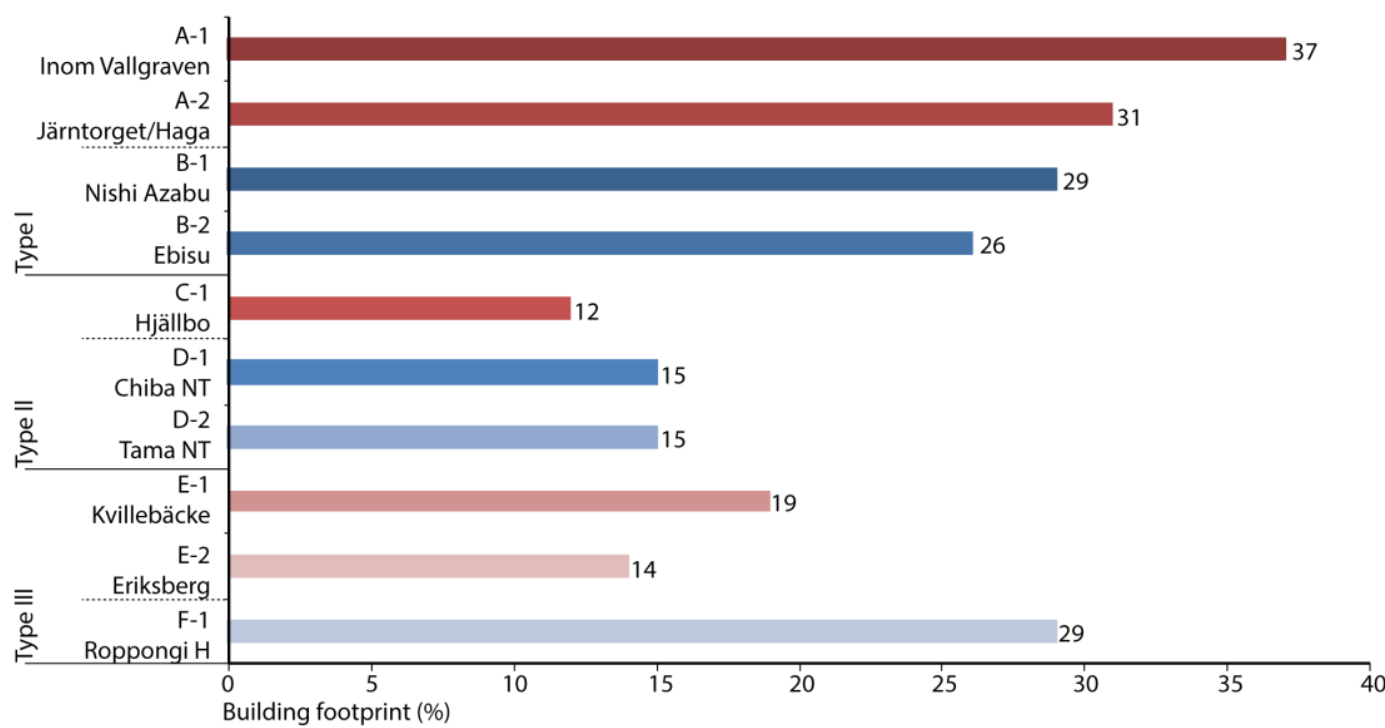

Figure 6. Graph over building footprint densities in the ten study areas. The horizontal axis shows the density as a percentage of the total area. 


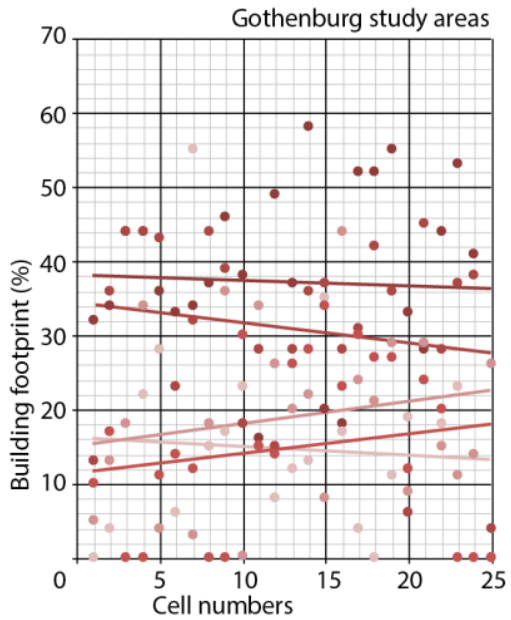

Footprint density by cells

- A-1.Inom Vallgraven

- A-2. Järntorget/Haga

- C-1. Hjällbo

- E-1. Kvillebäcke

E-2. Eriksberg

Linear trendline

- A-1.Inom Vallgraven

- A-2. Järntorget/Haga

- C-1. Hjällbo

- E-1. Kvillebäcke

- E-2. Eriksberg

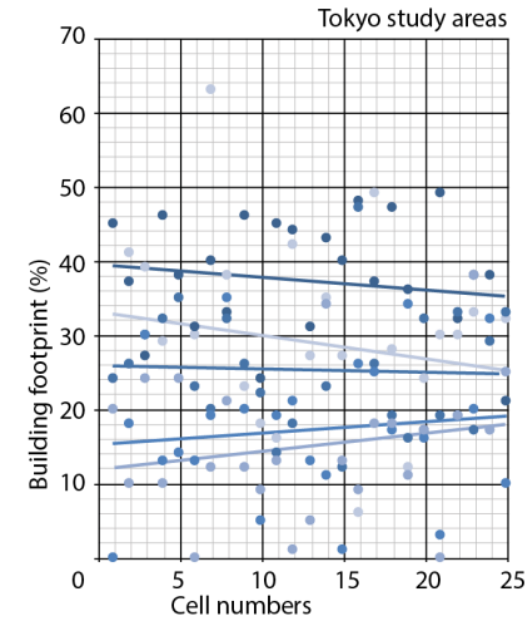

Footprint density by cells

- B-1. Nishi Azabu

- B-2. Ebisu

- D-1. Chiba NT

D-2. Tama NT

F-1. Roppongi $\mathrm{H}$

Linear trendline

- B-1. Nishi Azabu

- B-2. Ebisu

- D-1. Chiba NT

- D-2. Tama NT

F-1. Roppongi H

Figure 7. Graphs showing the distribution of the density of each cell in the study areas.
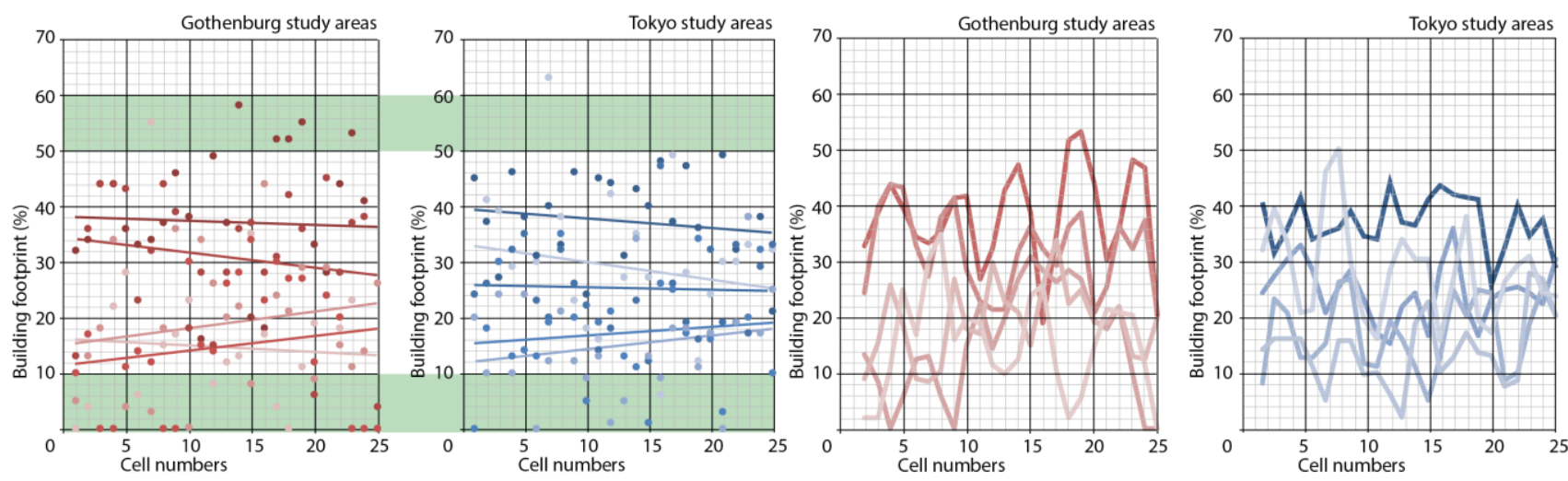

Figure 8. Four graphs showing the distribution of density trends in both cities. The images to the left show the median level density while the images to the right show the general pattern of density distribution between the cells.

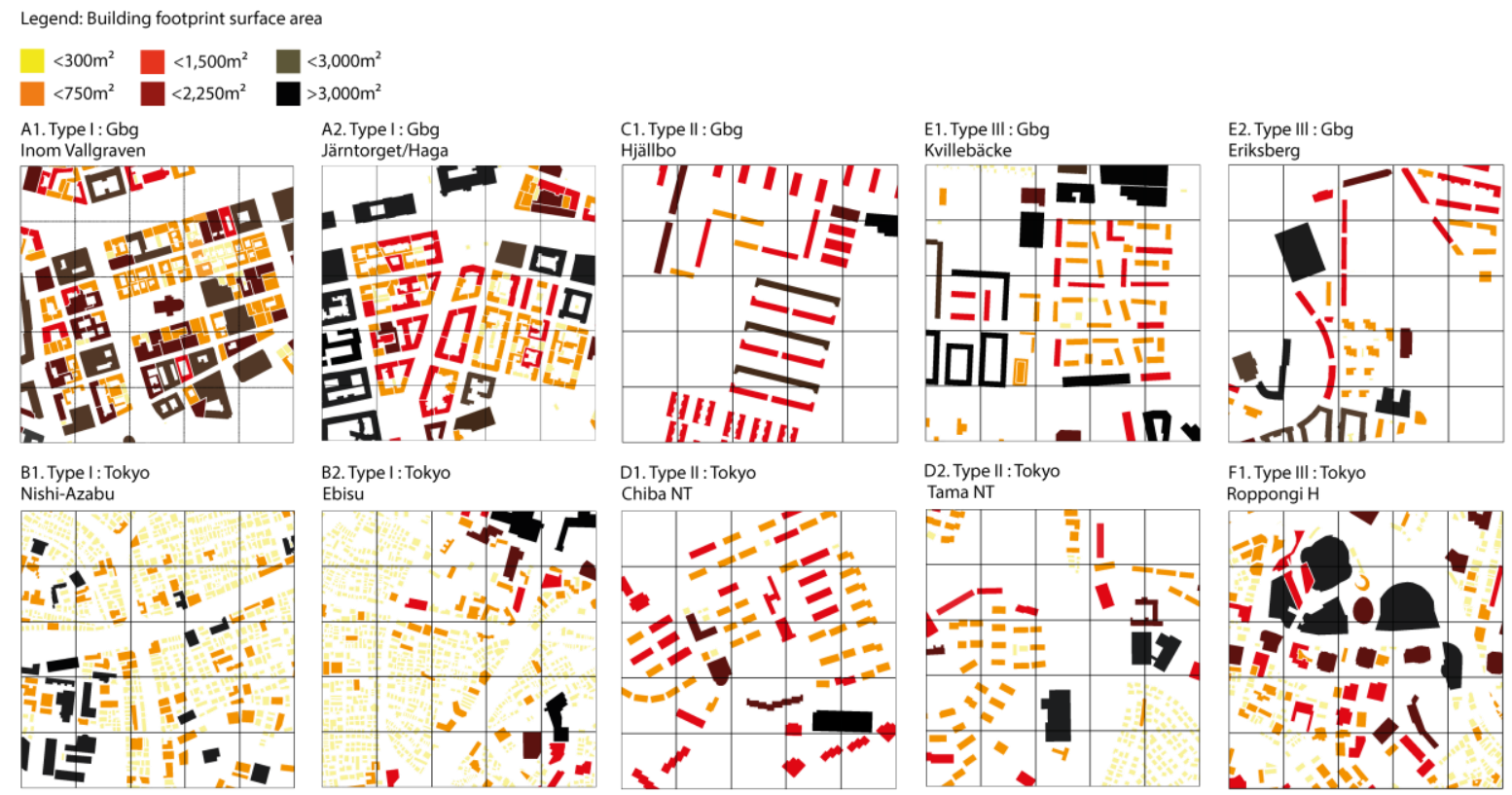

Figure 9. Building footprints in the ten study areas color-coded according to their scale; first phase of analysis. 


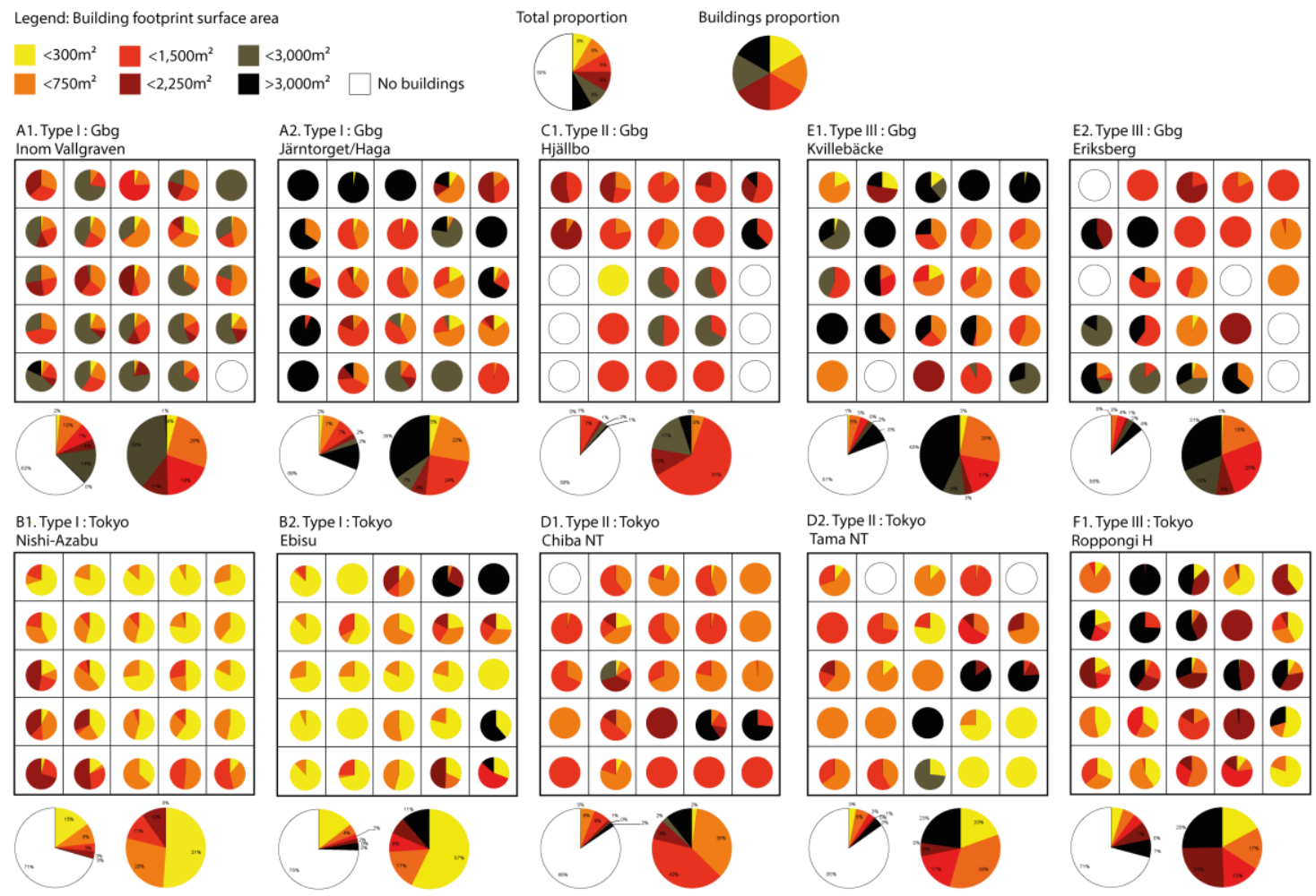

Figure 10. Diagrams showing the scale distributions of building footprints as well as the total proportions including unbuilt surfaces for each cell in the ten study areas; from the second phase of analysis.

However, looking at the proportions between the types within the same cities, we observed a gradual decrease of smaller scale buildings from Type 1, and to Type 3, and then to Type 2 . Also, more vacant lots are observed in Type 2 in both cities.

\section{Discussion}

The graph displaying the density analysis of the study sites showed generally higher density in Type 1 areas in both cities. Gothenburg showed even higher density in those areas than Tokyo. The designed compact city areas of Type 3 in Gothenburg showed a much lower density, which was rather similar to that of the modernist designed Type 2 areas of Tokyo. The study of the median levels of density showed a much more even distribution of density in overall Tokyo, with a more consistently clustered density distribution throughout (see Figure 8). In Gothenburg, the highs and lows of the density were greater, with urban areas varying significantly from larger unbuilt sites to extremely dense sites. Type 1 Gothenburg areas showed much higher density than that of any other Type in both cities. Also here, extreme highs and lows were observed, compared to the more contained distribution of the Tokyo sites (see Figure 11).

When looking at the scale and distribution/diversity of building footprints across the study areas, including streets and unbuilt surfaces, the building shapes and configuration of Gothenburg's Type 3 areas exhibited resemblance to the reductionist oriented Type 2 areas of both cities, rather than the intended compact city type seen in Gothenburg Type 1 areas (see Figure 9). However, when looking at the distribution/diversity of the building footprints only, the results told a somewhat different story (see Figure 12). A comparison of the scales of building objects within each city showed an increasing scale from Type 1 to Type 2 and then to Type 3. Also, the relative number of buildings found in the respective study areas was highest in Type 1 areas and lowest in Type 2 areas in both cities, while Type 3 areas remained in-between. However, assuming that the whole of a Type 3 area would be developed in the same manner as the individual intensification projects, Gothenburg's Type 3 actually began to resemble Type 1, while in Tokyo, this adjusted value of Type 3 resembled that of Type 2 areas (see Figure 12). The density and mixed-use oriented design approach in Tokyo (Type 3) had thus resulted in a lower quantity of buildings in a dense composition, emulating the density of Type 1 but the building scale and distribution of Type 2 . In Gothenburg, it was unclear if the densities or building scales exhibited any characteristics similar to the emerged urban form of Type 1 . The slight increase of density was rather insignificant. However, the increase of the number of buildings found in the two Type 3 areas, almost to the level found in Type 1 areas, seemed to indicate some of the characteristics found in Type 1. 


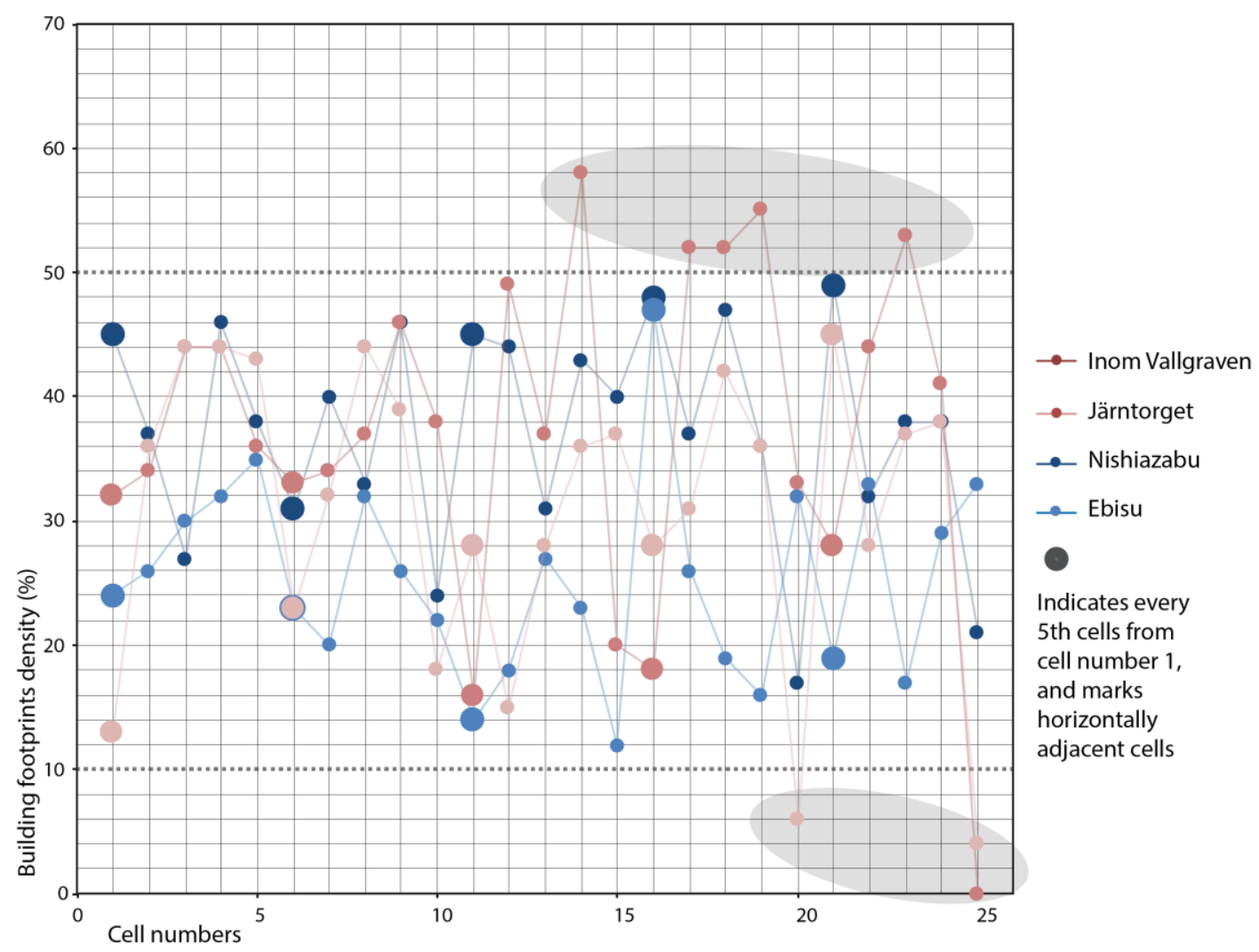

Figure 11. Graph showing the density of each cell in all four Type 1 areas. Highs and lows in Gothenburg are shaded grey.

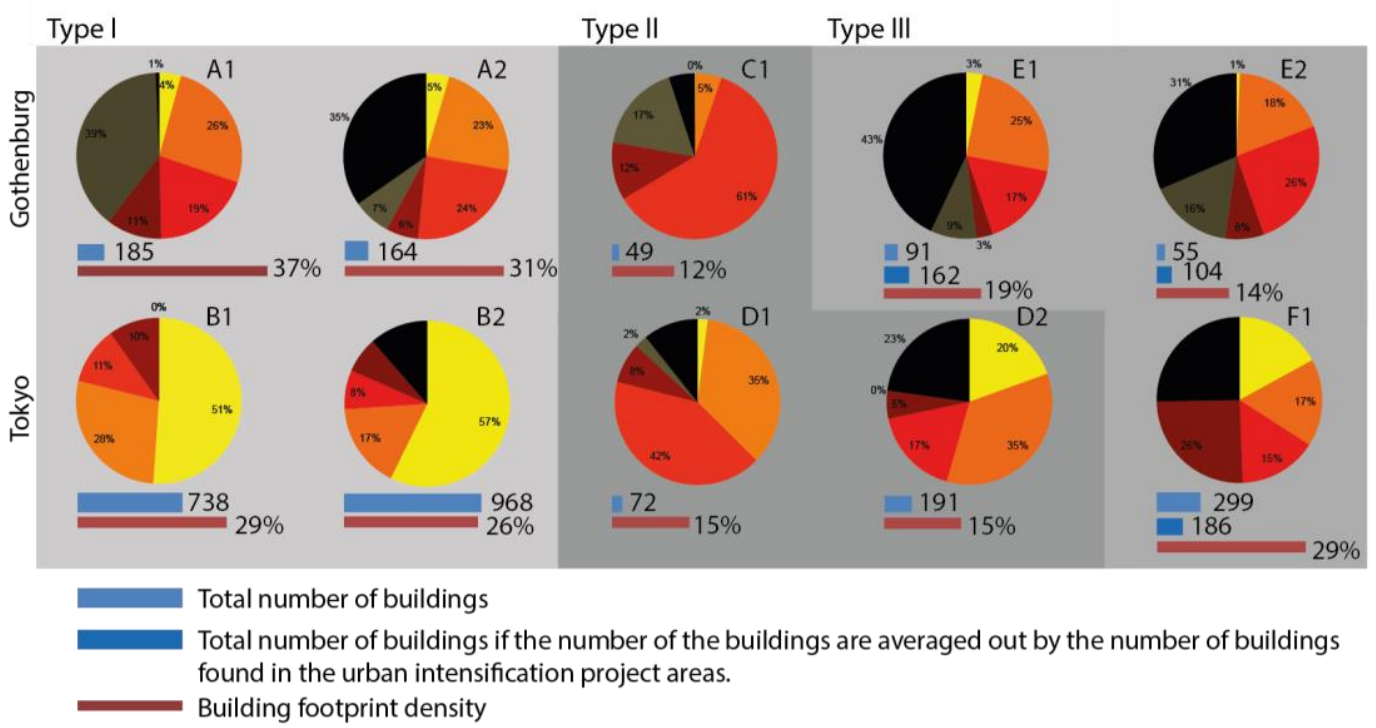

Figure 12. Comparisons of scale distributions of the building footprints in the two cities. Numbers of buildings found in each study area is shown. As a comparison, for Type 3 the figure also shows the projected number of buildings as if the whole study area would have contained the same number of buildings as the intensification development sites. The percentage of building footprint density is provided for reference.

Furthermore, it might be speculated that wider roads and existence of larger public areas are contributing factors to the variation of density in Gothenburg seen in Figure 11. A quick tracking of visible parking spaces in two of the areas in Gothenburg and Tokyo showed larger parking spaces distributed less evenly in the Gothenburg Type 1 area (see Figure 13).
It is not surprising that the results showed reduced density and less diversity in areas designed with the reductionist approach (Type 2) compared to the areas designed with a density and diversity oriented approach (Type 3 ) in both cities. However, the observation that areas designed compact city areas in ongoing urban intensification programs in Gothenburg have a 
density that was closer to that of the suburban Million Program area, than to the density of the city core seems more remarkable. This might be due to the fact that these intensification plans were subjected to a waterfront development where the 'Compact city' motto is immediately followed by a 'Close to green areas' motto (Gothenburg City Council, 2012). To confirm this assumption, an additional analysis was carried out, focusing only on the project development areas, thus disregarding previously existing green areas and surrounding housing areas (see Figure 14). When the result was compared to the total scale distribution and density of the study areas, it displayed slightly increased density. However, the building scale distributions in the newly built intensification areas were much simplified, resulting in less diversity of scales compared to what was found in the total areas. This seemed to indicate that while the density efforts emulated Type 1 areas, the scale distribution followed the pattern observed in Type 2 areas.

For Tokyo, the results showed designed compact city of Type 3 actually displaying an overall density similar to the Type 1 areas. Once again, we singled out the Roppongi Hills project area and re-analysed the density and the scale distribution and compared the results with the total study area and also to the other areas studied in Tokyo (see Figure 15). The extended analysis showed that also in this case, the project area had an increased density. However, it also showed a reduced proportion of smaller scale buildings, resulting in less buildings with footprints of under $1,500 \mathrm{~m}^{2}$ than in both Type 1, Type 2, and the rest of the Type 3 area. The secondary analysis of the Type 3 areas in both cities seemed to indicate that an increase of the density was possible to engineer through urban design, while the design of diversity of building scales was not.

To sum up the findings on density and diversity, it was only in Gothenburg that density distinguished Type 1 from Type 3 . An increase of building scales and uniformity of scale distribution was observed in Type 3 areas in both cities. The analysis of quantity of built objects was showed contrasting results in the Type 3 in both cities. However, higher density, a higher quantity of small-scale built objects and a more even distribution between the scales seemed to indicate the presence of a kind of compact city form in Type 3 areas in both cities, compared to Type 2 areas.
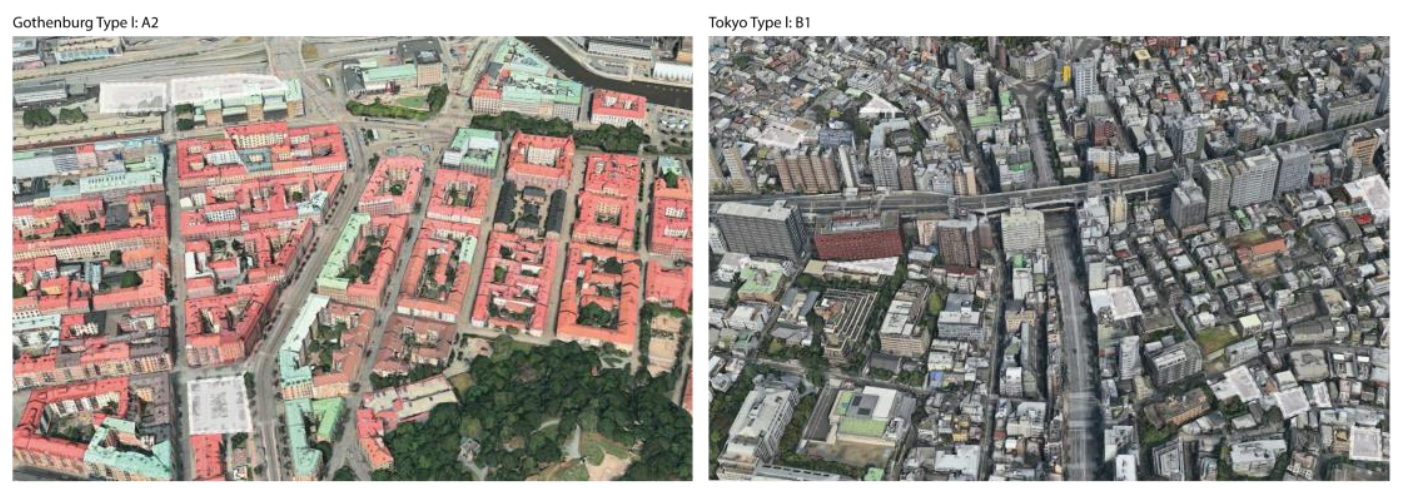

I. Visible ground level parking spaces

Figure 13. The bird's eye-view of Type 1 study areas in both cities with marked ground level spaces designated for parking.
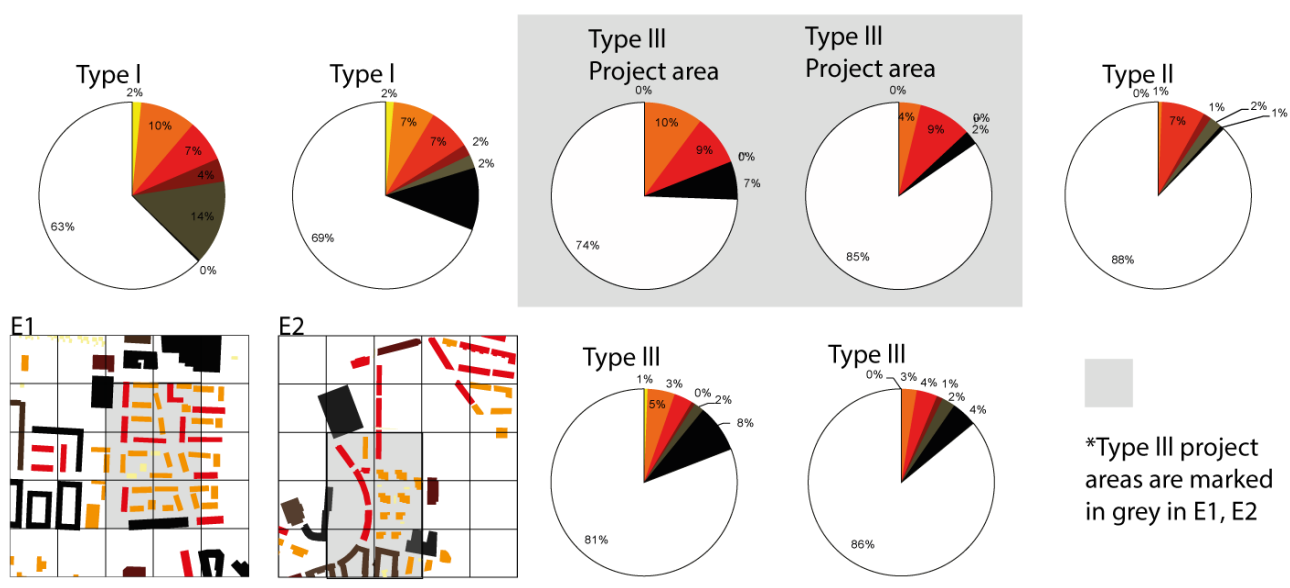

Figure 14. Proportions of scale distributions of building footprints of Type 3 areas in Gothenburg re-analysed focusing only on the newly developed parts of the study area. 


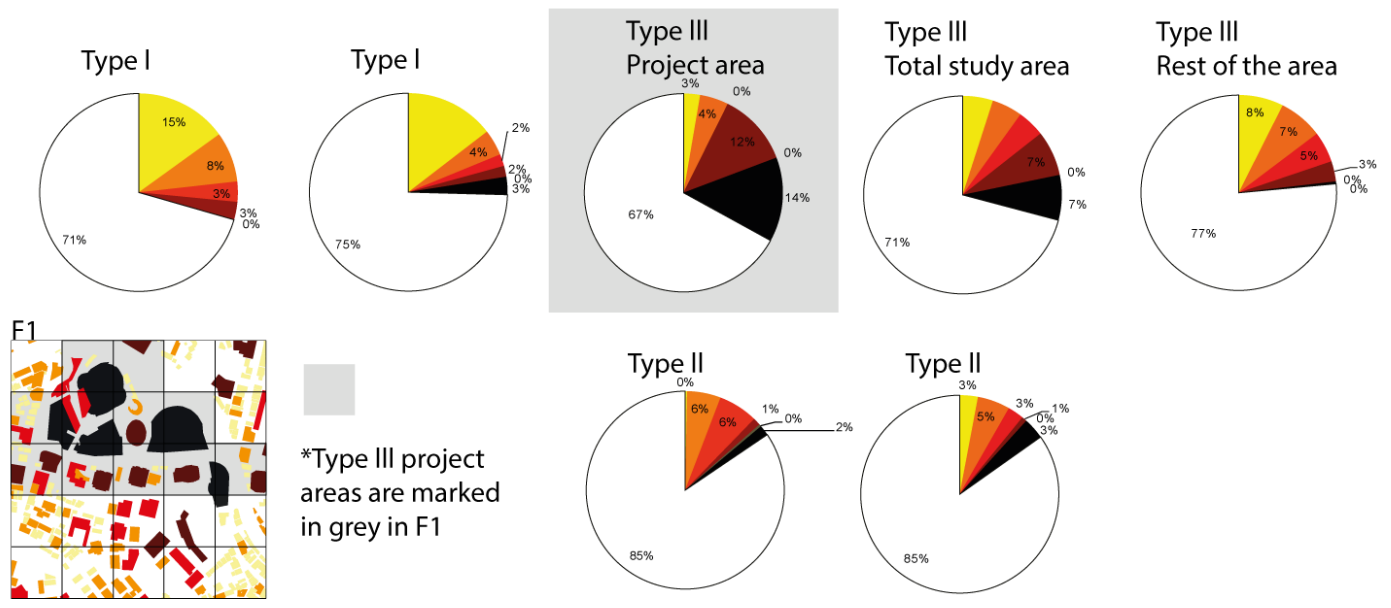

Figure 15. Re-analysis of the Type 3 area in Tokyo. The overall Roppongi area is divided into the Roppongi Hills project area and the surrounding area.

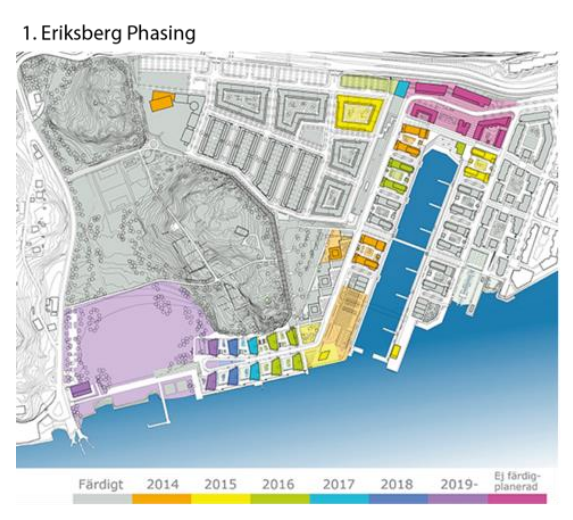

*These images are collected from the following websites.

1. http://www.vastraeriksberg.se/utbyggnadplan/ 2. 3. 4. http://www.kvillebacken.se/om-kvillebaecken/kvarteren

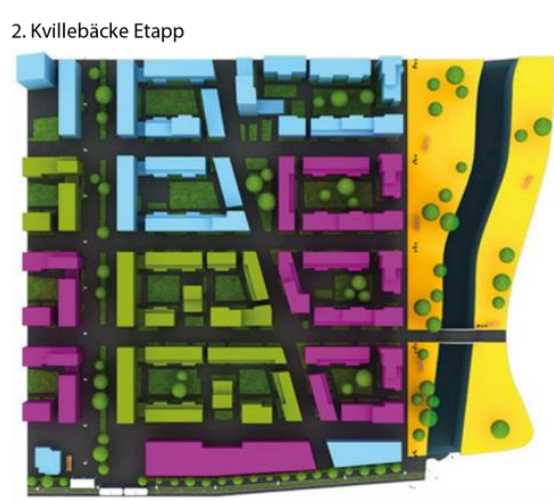

3. Kvillebäcke assigned firms

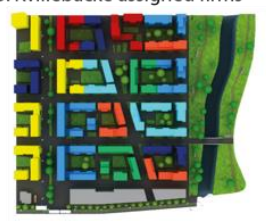

4. Kvillebäcke location of other than residential functions
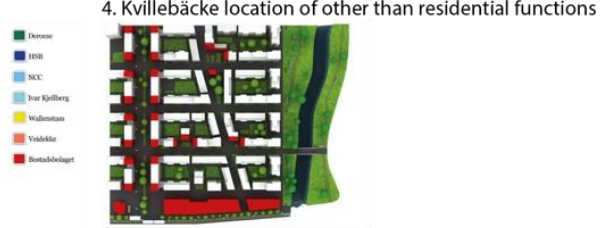

Figure 16. Images show the information regarding the phasing of the project development. (Kvillebäcken, retrieved 2015).

If we apply Ahern's (2011) resilience characteristics shown in Figure 1, increased density and number of built objects potentially indicate the required multiplicity of elements and components required for redundancy and modularization. Benefits of multiple, diverse agents for resilient and adaptive urban systems have been pointed out by many researchers (Bettencourt, 2013; Bettencourt \& West, 2010; Glaeser, 2011; Quigley, 1998), and the characteristics of the emerged Type 1 seem to concur with those characteristics, if we consider a parcel as an individual agent (HoffmannAxthelm, 1993, 1996, cited in Scheurer, 2007). For Type 3 this is less obvious. An emergent system could be regarded as a process of incremental adaptivity by diverse agent's self-modification, and interaction, and the characteristics of emergent urban form is the outcome of this process. Even though the urban intensification projects in Gothenburg waterfronts, represented by the two Type 3 study areas Kvillebäcken and Eriksberg, aim to implement incremental development strategies with varying phases of construction assigned to multiple actors, Figure 16 shows that this incrementality is designed already during the initial master planning process.

The images in Figure 16 also show how the planned diversity of employed design firms and of urban functions is already extant at this early stage. A certain degree of density and variety of scales may possibly be emulated in planning processes if the parameters are set to achieve such characteristics. However, it seems that true diversity of scales as consequences of emergent design processes through adaptation and incremental development is not delivered by pre-designed incrementality with a pre-assigned and controlled diversity.

One critique of the Kvillebäcken and Eriksberg areas in Gothenburg concerns the high rents and purchase fees in the project areas. The average rent per $\mathrm{m}^{2}$ per year in Gothenburg for a one room apartment is 1,251 SEK (Statistics Sweden, 2015), while the lower rent scale for a one room apartment is 2,101 SEK per $\mathrm{m}^{2}$ 
and year in Kvillebäcken (Kjellberg, 2013). The rent in Roppongi Hills residence is also much higher than the average of the same ward, costing 7,480 JPY per $\mathrm{m}^{2}$ per month (Moriliving, 2015) compared to the 4,409 JPY average per month (REINS, 2015). Newly built apartments being expensive is not a new phenomenon. However, when large neighbourhoods are solely composed of costly new apartments, any diversity of the socio-economic demography can hardly be achieved. Kvillebäcken is especially criticized for negative gentrification, not least since the development of the site involved the removal of existing buildings and activities (Thörn, 2013). In this case, an incremental 'adaptive process' through time and space could proven to contribute more to the resilient characteristics of urban form rather than what was achieved through the predesigned and pre-determined processes only mimicking incrementality (Alexander, 1965; Neuman, 2005).

In comparison with Gothenburg, the Type 1 study areas with emergent urban form in Tokyo showed slightly lower but more uniform rates of density, with higher proportion of smaller buildings and overall quantity of buildings (see Figures 8 and 10). The distribution of this type is prevalent in the overall Tokyo metropolitan area. It is interesting to discuss whether the less problematic class segregation issues observed in Tokyo (Fujita \& Hill, 2012) might relate to these urban-form characteristics. It is speculated that contributing urban form factors might be a well-networked public transportation, renewability of aged buildings and housing stocks, smaller scale real-estate development, and less strict land use which create micro pattern of land-use with mixed functions (Fujita \& Hill, 2012). Presumably, such patterns of multi-functionality, redundancy, modularization and diversity (Ahern, 2011) can be seen to increase socioeconomic resilience to the benefit of less affluent citizens.

Tokyo is operating under an overarching 'rulebased' planning approach with a highly mixed accumulative zoning, where building standard laws are consistent to 'planning by coding' (Marshall, 2012). The implementation of the zoning codes is top-down, thus indicating, also the 'planning by development control'. Compared to Type 2, shaped through 'planning by design', and Type 3, delivered through 'planning by development control', and 'planning by design', the question whether 'planning by coding' generates more emergent behaviour with incremental adaptive changes as seen in Type 1 needs to be further studied. Also, our understanding of how Tokyo's rule-based planning approach-and its outcomes-came into being would be further strengthened from understanding more about how the historical background of urban development processes in Tokyo plays into this. First, the lack of centralized planning can be explained by the post WW II situation. After the destruction of the city structure during the war and the great Kanto earth- quake, a prevailing lack of resources resulted in a lack of centralized planning, leaving the city to be reconstructed by citizen efforts, neighbourhood by neighbourhood, mimicking structures existing before the destruction (Hein, 2010; Okata \& Murayama, 2011). Second, land reform policy of post WWII forced agricultural landlords to sell land to smaller farmers, resulting in piecemeal land divisions with a diversity of smaller scale independent actors (Kawagoe, 1999). Third, as railways were constructed the areas were developed around each station, so that the next station could be expanded with the capital gains from the real-estate development, incrementally expanding the city station by station (Okata \& Murayama, 2011).

\section{Conclusions}

This paper sets out to answer the question: What are the differences in outcome of different planning approaches in relation to urban characteristics, such as density and diversity?

We have shown how different planning approaches seem to deliver very different outcomes when it comes density and diversity of built objects. While the process of Type 3 development (designed compact urban form) to some extent emulates Type 1 (emergent compact urban form), some of the differences seem to be critical to the detriment of Type 3 planning:

1. The time factor. By completely eliminating the existing building stocks and activities on site, as was done in the Kvillebäcken area, the planners also eliminated the time factor, leading to a total lack of incrementality and with no remaining population to engage in postdestruction piecemeal reconstruction.

2. The lack of diversity of building scales and absence of smaller estate patterns. Even with the efforts to involve multiple design and development companies to create diversity, the uniformity of overall scale still remains. Also, higher costs in larger scale development projects seems to contribute to a less diverse mix of socio-economical demographics.

3. Employment of a top-down planning hierarchy. The main planning body analyses and draws up a form plan, which is then approved by the city council. Multi-actor participation is only served through designing individual buildings assigned to them centrally, through 'planning by design' and 'development control' (Marshall, 2012).

Here this study might be able to contribute in relation to the how planning is carried out in Gothenburg, currently mixing 'planning by design' with 'planning by de- 
velopmental control' (Marshall, 2012). We have shown how parameters, such as timing, density, building scale diversity, and decentralization of planning and design activities to multiple actors are critical factors also in large scale development projects, for example in brown-field regeneration or urban infill areas. Although these parameters need to be studied more in-depth, with consideration to the local context for understanding the optimal level of timing, density and building scale in site areas. The 'planning by coding' (Marshall, 2012) strategy, with 'generative' rules, seems to offer a promising third path also in Swedish urban regeneration for density and mixed use, as seen with the rulebased approach in Japan. Consequently, feasibility studies for implementation of 'planning by coding' or rule-based planning strategies should be carried out to support incrementality whenever possible.

\section{Conflict of Interests}

The authors declare no conflict of interests.

\section{References}

Ahern, J. (2011). From fail-safe to safe-to-fail: Sustainability and resilience in the new urban world. Landscape and Urban Planning, 100(4), 341-343.

Alexander, C. (1965). A city is not a tree. Architectural Forum, 122(1/2), 58-62.

Batty, M., \& Marshall, S. (2012). The origins of complexity theory in cities and planning. In J. Portugali, $\mathrm{H}$. Meyer, E. Stolk \& E. Tan (Eds.), Complexity theories of cities have come of age (pp. 21-46). Berlin, Germany: Springer Berlin Heidelberg.

Bettencourt, L. (2013). The kind of problem a city is. In D. Offenhuber \& C. Ratti (Eds.), Die Stadt Entschlusseln: Wie Echtzeitdaten Den Urbanismus Verandern: Wie Echtzeitdaten den Urbanismus Verandern (pp. 175187). Heidelberg, Germany: Birkhauser.

Bettencourt, L., \& West, G. (2010). A unified theory of urban living. Nature, 467(7318), 912-913.

Boplats. (2014). Boplats i siffror. Boplats. Retrieved from https://nya.boplats.se/om/statistik

Bramley, G., \& Power, S. (2009). Urban form and social sustainability: The role of density and housing type. Environment and Planning B: Planning and Design, 36(1), 30-48.

Brand, F. S., \& Jax, K. (2007). Focusing the meaning(s) of resilience: Resilience as a descriptive concept and a boundary object. Ecology and Society, 12(1), 23.

Bristow, G. (2010). Resilient regions: Re-'place'ing regional competitiveness. Cambridge Journal of Regions, Economy and Society, 3(1), 153-167.

Bureau of Urban Development Tokyo Metropolitan Government. (2010). Article 05-NT population trends. Bureau of Urban Development Tokyo Metropolitan Government. Retrieved from http://www.toshiseibi.me tro.tokyo.jp/bosai/tama/pdf/tama09.pdf

Burton, E. (2001). The compact city and social justice. In Proceedings of the housing studies association spring conference on housing, environment and sustainability. York: University of York.

Carlino, G. A., Chatterjee, S., \& Hunt, R. M. (2007). Urban density and the rate of invention. Journal of Urban Economics, 61(3), 389-419.

Chelleri, L., \& Olazabal, M. (2012). Multidisciplinary perspectives on urban resilience: $A$ workshop report. Bilbao, Spain: BC3, Basque Centre for Climate Change.

Chiba Prefecture Government. (2013). Chiba new town. Chiba Prefecture Government. Retrieved from: https://www.pref.chiba.lg.jp/kigyou/nt/index-e.html

Churchman, A. (1999). Disentangling the concept of density. Journal of Planning Literature, 13(4), 389411.

Commission of the European Communities. (1990). Green paper on the urban environment. Luxembourg: Publications Office of the European Office.

Commission of the European communities. (2011). Cities of tomorrow: Challenges, visions, ways forward. Luxembourg: Publications Office of the European Office.

Davoudi, S., Shaw, K., Haider, L. J., Quinlan, A. E., Peterson, G. D., Wilkinson, C. . . ., \& Davoudi, S. (2012). Resilience: A bridging concept or a dead end? 'Reframing' resilience: Challenges for planning theory and practice interacting traps: Resilience assessment of a pasture management system in Northern Afghanistan Urban Resilience: What does it mean in planning practice? Resilience as a useful concept for climate change adaptation? The politics of resilience for planning: A cautionary note. Planning Theory \& Practice, 13(2), 299-333.

Dempsey, N., Brown, C., \& Bramley, G. (2012). The key to sustainable urban development in UK cities? The influence of density on social sustainability. Progress in Planning, 77(3), 89-141.

Ducom, E. (2008). Tama new town, west of Tokyo: Analysis of a shrinking suburb. HAL-Inria. Retrieved from http://hal.inria.fr/docs/00/21/59/89/PDF/LaUPDUCOM.pdf

Echanove, M. (2013). Beyond the informal: Reconceptualizing Mumbai's urban development (MMG Working Paper). Goettingen, Germany: Max Planck Institute for the Study of Religious and Ethnic Diversity

Eom, H.-J., \& Cho, G.-H. (2015). Exploring thresholds of built environment characteristics for walkable communities: Empirical evidence from the Seoul metropolitan area. Transportation Research Part $D$ : Transport and Environment, 40, 76-86.

Fujita, K., \& Hill, R. C. (2012). Residential income inequality in Tokyo and why it does not translate into classbased segregation. In T. Maloutas \& K. Fujita (Eds.), Residential segregation in comparative perspective: Making sense of contextual diversity (pp. 37-68). Abingdon, UK: Ashgate Publishing Group. 
Glaeser, E. L. (2011). The triumph of the city: How our greatest invention makes us richer, smarter, greener, healthier, and happier. New York: Penguin Press.

Gothenburg City Council, (2011). Hållbar utveckling I Kvillebäcken. Gothenburg: City of Gothenburg.

Gothenburg City Council. (2012). Rivercity Gothenburg Vision. Gothenburg: City of Gothenburg.

Gothenburg City Council. (2013). Statistisk Årsbok. Gothenburg City Council. Retrieved from http://www 4.goteborg.se/prod/sk/statistik/statistikR5.nsf

Gothenburg City Council. (2014). Statistisk Årsbok. Gothenburg City Council. Retrieved from http://www 4.goteborg.se/prod/sk/statistik/statistikR5.nsf

Gothenburg City Council. (2015). Statistisk Årsbok. Gothenburg City Council. Retrieved from http://www 4.goteborg.se/prod/sk/statistik/statistikR5.nsf

Gunderson, L. H., \& Holling, C. S. (2002). Panarchy: Understanding transformations in human and natural systems. Chicago, IL: Island Press.

Haigh, F., Ng Chok, H., \& Harris, P. (2011). Housing density and health: A review of the literature and health impact assessments. Sydney: UNSW Research Centre for Primary Health Care and Equity.

Hein, C. (2010). Shaping Tokyo: Land development and planning practice in the early modern Japanese metropolis. Journal of Urban History, 36(4), 447-484.

Heinonen, J., \& Junnila, S. (2011). Implications of urban structure on carbon consumption in metropolitan areas. Environmental Research Letters, 6(1), 014018.

Hoffmann-Axthelm, D. (1993). Die dritte Stadt. Bausteine eines neuen Gründungsvertrages. Frankfurt (M), Germany: Suhrkamp.

Hoffmann-Axthelm, D. (1996). Anleitung zum Stadtumbau. Frankfurt (M), Germany: Campus.

Homer-Dixon, T. (2011). Complexity science. Oxford Leadership Journal, 2(1), 1-15.

Kjellberg, I. (2013). Nu startat vi uthyrningen I Kvillebäcken. Ivar Kjellberg Fastighetes $A B$. Retrieved from http://ikfab.kjellberg.se/nu-startar-vi-uthyrning en-i-kvillebacken

Jacobs, J. (1961). The death and life of great American cities. New York: Random House.

Kawagoe, T. (1999). Agricultural land reform in postwar Japan: Experiences and issues (Vol. 2111). World Bank Publications.

Kearney, A. R. (2006). Residential development patterns and neighborhood satisfaction: Impacts of density and nearby nature. Environment and Behavior, 38(1), 112-139.

Kvillebäcken. (n.d.). Kvarteren. Kvillebäcken. Retrieved from http://www.kvillebacken.se/om-kvillebaecken/ kvarteren

Laurian, L., Crawford, J., Day, M., Kouwenhoven, P., Mason, G., Ericksen N., Beattie, L. (2010). Evaluating the outcomes of plans: Theory, practice, and methodology. Environment and Planning B: Planning and Design, 37(4), 740-757.
Lee, J., Kurisu, K., An, K., \& Hanaki, K. (2015). Development of the compact city index and its application to Japanese cities. Urban Studies, 52(6), 1054-1070.

Leffers, D. (2015). Urban sustainability as a "boundary object": Interrogating discourses of urban intensification in Ottawa, Canada. In C. Isenhour, G. McDonogh, \& M. Checker (Eds.), Sustainability in the global city: Myth and practice (pp. 329-349). Cambridge, UK: Cambridge University Press.

Lilja, E., \& Pemer, M. (2010). BoendesegregationOrsaker och mekanismer: En genomgång av aktuell forskning. Karlskrona: Boverket

Manaugh, K., \& Kreider, T. (2013). What is mixed use? Presenting an interaction method for measuring land use mix. Journal of Transport and Land Use, 6(1), 6372.

Manesh, S. V., \& Tadi, M. (2011). Sustainable urban morphology emergence via complex adaptive system analysis: Sustainable design in existing context. Procedia Engineering, 21, 89-97.

Marshall, S. (2011). Urban coding and planning. London and New York: Routledge.

Marshall, S. (2012). Planning, design and the complexity of cities. In J. Portugali, H. Meyer, E. Stolk, \& E. Tan (Eds.), Complexity theories of cities have come of age (pp. 191-206). Berlin: Heidelberg: Springer Berlin Heidelberg.

Merlino, K. R. (2011). Urban grain and the vibrancy of older neighbourhoods: Metrics and measures. In Considering research: Reflecting upon current themes in architectural research (pp. 477-488). Detroit, USA: Lawrence Tech University.

Minato City. (2012). Minato-ku of population and number of households (based on the Basic Resident Register). 2012 (Number of Population and Households in Minato-ku, Tokyo). Retrieved from http://www. city.minato.tokyo.jp/toukeichousa/kuse/toke/jinko/ji nko/index.html

Mindali, O., Raveh, A., \& Salomon, I. (2004). Urban density and energy consumption: A new look at old statistics. Transportation Research Part A: Policy and Practice, 38(2), 143-162.

Moriliving. (2015). Roppongi Hills Residence. Moriliving. Retrieved from http://www.moriliving.com/en/esta te/residence/roppongihills

Muraca, B., \& Voget-Kleschin, L. (2011). Strong sustainability across culture(s). In G. Banse, G. L. Nelson, \& O. Parodi (Eds.), Sustainable development-The cultural perspective: Concepts, aspects, examples (pp. 187201). Berlin: Edition Sigma.

Nationalencyklopedin. (2015). miljionprogrammet. NE. Retrieved from http://www.ne.se/uppslagsverk/ency klopedi/lång/miljonprogrammet

Neuman, M. (2005). The compact city fallacy. Journal of Planning Education and Research, 25(1), 11-26.

OECD. (2012). Green growth studies, compact city policies: A comparative assessment. Paris, France: OECD 
Publishing.

Offenhuber, D., \& Ratti, C. (2014). Decoding the city: Urbanism in the age of big data. In EBOOK PACKAGE Arts and Architecture 2014. Basel: De Gruyter Birkhäuser.

Okata, J., \& Murayama, A. (2011). Tokyo's urban growth, urban form and sustainability. In A. Sorensen \& J. Okata (Eds.), Megacities (Vol. 10, pp. 15-41). Tokyo: Springer Japan.

Oliveira, V., \& Pinho, P. (2010). Evaluation in urban planning: Advances and prospects. Journal of Planning Literature, 24(4), 343-361.

Page, S. E. (2011). Diversity and complexity. Princeton, NJ: Princeton University Press.

Planning and Building Committee of Gothenburg. (2014). Development Strategy Göteborg 2035. Gothenburg: City of Gothenburg.

Quigley, J. M. (1998). Urban diversity and economic growth. Journal of Economic Perspectives, 12(2), 127138.

REINS. (2015). REINS Tower. REINS. Retrieved from http:// www.reins.or.jp/pdf/trend/sc/sc_201501-03.pdf

Rowley, A. (1994). Definitions of urban design: The nature and concerns of urban design. Planning Practice and Research, 9(3), 179-197.

Scheurer, J. (2007). Compact city policy: How Europe rediscovered its history and met resistance. The Urban Reinventors, 2. Retrieved from http://www.urban reinventors.net/2/scheurer/scheurer-urbanreinvent ors.pdf

Shane, D. G. (2005). Recombinant urbanism: Conceptual modeling in architecture, urban design, and city theory. New York, USA: Wiley.

Shibuya City. (2010). Statistics data. Population by basic resident register, alien reistration. Retrieved from http://www.city.shibuya.tokyo.jp

Stadshem. (2015a). Haga. Stadshem. Retrieved from http://www.stadshem.se/omrade/haga

Stadshem. (2015b). Inom Vallgraven. Stadshem. Retrieved from http://www.stadshem.se/omrade/inom -vallgraven

Statistics Sweden. (2015). Nybyggnad av bostäder. SCB. Retrieved from http://www.scb.se/BO0101

Taylor, P. (2003). Time: From hegemonic change to everyday life. In S. Holloway, S. Rice, \& G. Valentine (Eds.), Key concepts in geography (pp. 146-152).
London, United Kingdom: Sage Publications.

The Japan Times. (2011). The aging issue of Chiba New Town. The Japan Times. Retrieved from http://www. japantimes.co.jp/community/2011/11/01/how-tos/ja pans-new-towns-are-finally-getting-too-old/\#.VnFDOp MrlOo

Thörn, C. (2013). Här utplånas mångfalden. Arkitektur. Retrieved from www.arkitektur.se/har-utplanasmangfalden

TILLIT. (2010). TILLIT: Hjällbo. Presentation documentation for Den nödvändiga samverkan for Gothenburg City. TILLIT. Retrieved from http://www4.goteborg. se/prod/storstad/dalis2.nsf/vyFilArkiv/TILLIT.Hjallbo. Samv.25.feb.ppt/\$file/TILLIT.Hjallbo.Samv.25.feb.ppt

Tokyo Metropolitan Government. (2012). Tokyo's history, geography, and population. Tokyo Metropolitan Government. Retrieved from http://www.toukei. metro.tokyo.jp/tnenkan/tn-eindex.htm

UN Habitat. (2011). The economic role of cities. United Nations Human Settlements Programme 2011. Nairobi, Kenya: United Nations Human Settlements Programme.

UN Habitat. (2014a). A new strategy of sustainable neighbourhood planning: Five principles. Nairobi, Kenya: United Nations Human Settlements Programme.

UN Habitat. (2014b). The economics of urban form: A literature review. Nairobi, Kenya: United Nations Human Settlements Programme 2014.

UN Habitat. (2014c). Urban patterns for a green economy leveraging density. Nairobi, Kenya: United Nations Human Settlements Programme.

UN Habitat. (2015). Issue Paper On Urban And Spatial Planning And Design. Nairobi, Kenya: United Nations Human Settlements Programme 2015.

Västraeriksberg. (2013). Utbyggnadsplan. Västraeriksberg. Retrieved from http://www.vastraeriksberg.se/ utbyggnadplan

Wilkinson, C. (2011). Social-ecological resilience: Insights and issues for planning theory. Planning Theory, 11(2), 148-169.

Yokohari, M., Amemiya, M., \& Amati, M. (2006). The history and future directions of greenways in Japanese new towns. Landscape and Urban Planning, 76(1-4), 210-222.

\section{About the Authors}

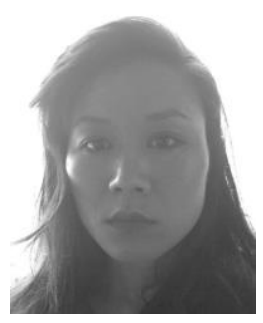

\section{Hye Kyung Lim}

Hye Kyung Lim is a PhD candidate in the department of architecture at Chalmers University of Technology, Gothenburg, Sweden and is affiliated with Mistra urban futures Gothenburg. Her current research focuses on compact city strategies based on comparative studies of urban systems, and development of collaborative urban planning tools using both digital mapping on mobile devices and augmented reality based urban design methods. 


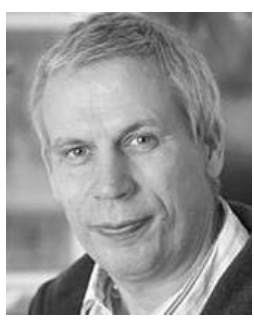

\section{Dr. Jaan-Henrik Kain}

Jaan-Henrik Kain is Professor in Urban Transformation and Planning Processes at Chalmers Architecture, Chalmers University of Technology, Gothenburg, Sweden. Current research topics include digital tools for inclusive planning, planning for urban ecosystem services, reviewing qualities, drivers and strategies for urban densification, and building democracy through waste management in development settings. 